\title{
The ICDP Lake Bosumtwi Drilling Project: A First Report
}

\author{
by Christian Koeberl, John Peck, John King, Bernd Milkereit, \\ Jonathan Overpeck, and Christopher Scholz
}

\section{Summary}

The 10.5-km-diameter, 1.07-Ma Bosumtwi impact crater was the subject of a multi-disciplinary and international drilling effort of the International Continental Scientific Drilling Program (ICDP) from July to October 2004. Sixteen different holes were drilled at six locations within the lake, to a maximum depth of $540 \mathrm{~m}$. A total of about $2.2 \mathrm{~km}$ of core material was obtained. Despite some technical and logistical challenges, the project has been very successful and it is anticipated that the first scientific results will be available in late 2005 .

\section{Introduction and Geological Setting}

The Bosumtwi impact crater, centered at $06^{\circ} 32^{\prime} \mathrm{N}$ and $01^{\circ} 25^{\prime} \mathrm{W}$ in Ghana, West Africa, is almost completely filled by a lake (Fig. 1). Lake Bosumtwi has been known to the scientific community since the beginning of the twentieth century, but its origin was the subject of controversy until the 1960s, when petrological and isotope geochemical studies on tektites and impact glasses showed evidence of a meteorite impact. Bosumtwi is one of 170 meteorite impact craters currently known on Earth and one of only four known impact craters associated with a tektite-strewn field (Koeberl et al., 1997). It is a well-preserved, complex impact structure with a pronounced rim, surrounded by a slight, near-circular depression and a $20-\mathrm{km}$-diameter outer ring of minor topographic highs. The crater is excavated in

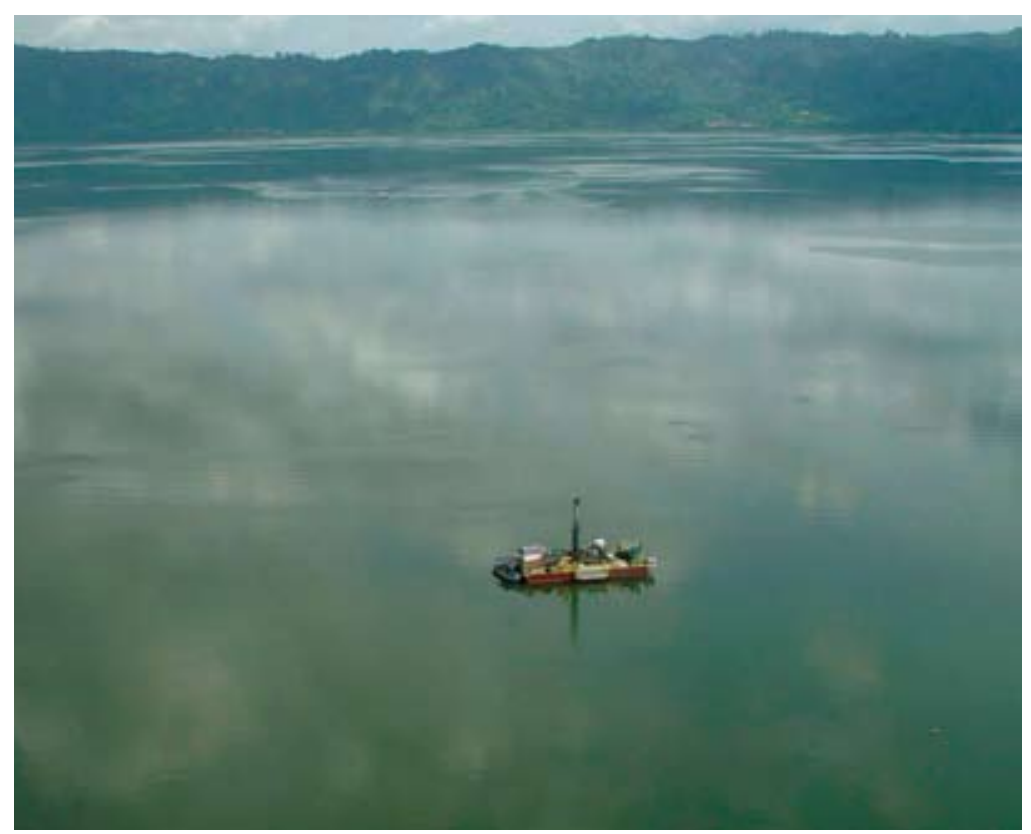

Figure 1. The GLAD-800 lake drilling system on Lake Bosumtwi.
2-Ga metamorphosed and crystalline rocks of the Birimian System, but only limited petrographic studies of rocks found along the crater rim and of ejecta (suevitic breccias) are available so far (Koeberl et al., 1998).

Recent petrographic and geochemical work confirmed the presence of shock metamorphic effects and the presence of a meteoritic component in the Ivory Coast tektites and the breccias at the crater (e.g., Koeberl et al., 1997, 1998).

Insights into the deep structure of the crater and the distribution and nature of ejected material and post-impact sediments were obtained by geophysical work over the past seven years, which included aeromagnetic and airborne radiometric maps, multi-channel seismic reflection and refraction profiles, and land- and barge-based gravity and magnetic studies. The first magnetic field studies of the structure were conducted in 1960 and revealed a central negative anomaly of $\sim 40 \mathrm{nT}$, attributed to a breccia lens below the lake sediments. Gravity measurements collected around the lake at that time reflected only the regional trends. In 1997 a high-resolution airborne geophysical survey revealed a halo-shaped magnetic anomaly (Plado et al., 2000). Seismic reflection and refraction data (Scholz et al., 2002; Karp et al., 2002) defined the position of a $1.9-\mathrm{km}$-diameter central uplift situated northwest of the center of the lake.

The goal of the integrated drilling, rock property, and surface geophysical study was to study the three-dimensional building blocks of the impact crater, delineate key lithological units, image fault patterns, and define alteration zones (Table 1). Results from the Lake Bosumtwi scientific drilling project are important for comparative studies and reevaluation of existing geophysical data from large terrestrial impact sites (for example, Sudbury, Vredeford, Chicxulub, and Ries).

Lake Bosumtwi possesses several important characteristics that make it well suited to provide a record of tropical climate change. First, because of the great age of the crater $(1.07 \mathrm{Ma})$ and its location in West Africa, the lake sediments can provide a long record of change in North African monsoon strength. Lake Bosumtwi lies in the path of the seasonal migration of the Intertropical 


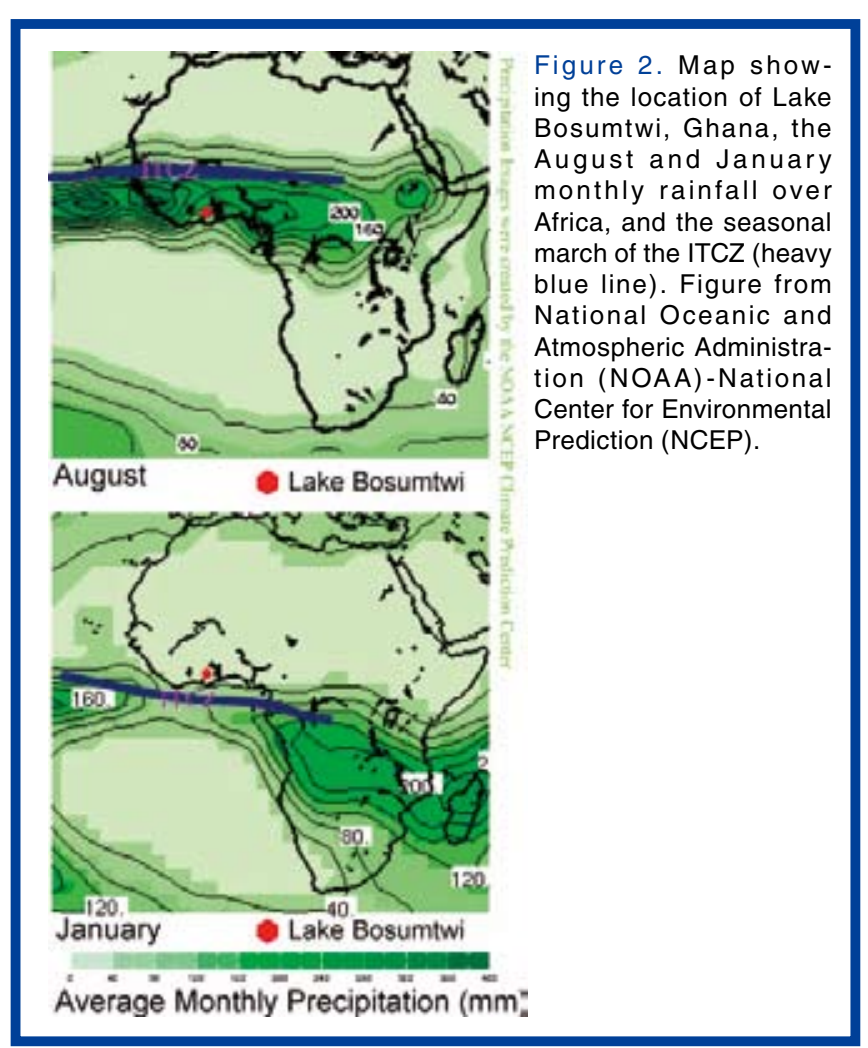

Convergence Zone (ITCZ), the atmospheric boundary between continental northeasterly trade winds and onshore southeasterly trade winds (Fig. 2). During summer months, the ITCZ migrates to the north of Lake Bosumtwi and moisture-laden southeasterly winds bring heavy, monsoonal precipitation to western Africa. The reverse occurs during winter months, as the ITCZ moves southward of Lake Bosumtwi and dry, aerosol-rich northeasterly trade winds (Harmattan) dominate over southern Ghana. Second, the high crater rim surrounding the lake results in a hydrologically closed basin with a water budget extremely sensitive to the precipitation and evapotranspiration balance. Third, the steep crater wall and deep lake basin limit wind-wave mixing of the water column. As a result, the deep water is anoxic, thereby limiting bioturbation and allowing for the preservation of laminated sediment varves and the potential for high-resolution (annual) paleoclimate reconstruction.

The goal of the sediment drilling program was to recover offset cores from multiple drill holes in order to obtain the complete 1-m.y. sediment record of paleoenvironmental change. The lake is at an ideal geographical location to provide data on past interannual to orbital-scale variations in the West African monsoon and Sahel drought. Lake Bosumtwi has accumulated a detailed record of varved lake sediments that can be used to monitor both past local and Sahel rainfall variations. Rainfall over much of sub-Sahara Africa was highly correlated on centennial and longer timescales. Such data will benefit not only Ghana, where rainfall-dependent agriculture comprises a large part of the economy, but also the large populations of the entire sub-Sahara region of West Africa. A complex record of changes in lake level, lake chemistry, climate, and vegetation history has been documented by previous studies of short piston cores (Talbot and Johannessen, 1992). More recent work has confirmed the potential of such paleoclimatic studies in addressing questions related to abrupt climate change (Peck et al., 2004; Brooks et al., 2005).

\section{ICDP Drilling Project Planning}

Recent studies have led to the realization that further insight can only be obtained from deep drilling. Such drilling is desirable for several reasons, including in terms of cratering studies. Bosumtwi is one of only two known young craters of this size, and it may have a crucial diameter at the changeover between a traditional complex crater with a central peak and a crater structure that has a central peak-ring system, perhaps similar to that of the Ries crater in Germany, which is twice as large. Drilling will serve to corroborate the geophysical studies and will provide material for geochemical and petrographic correlation studies between basement rocks and crater fill in comparison with tektites and ejected material.

The original proposal was to obtain cores at nine locations in the crater lake, with core lengths ranging from 50 to $1035 \mathrm{~m}$ and totaling $3 \mathrm{~km}$ of sediments and $1 \mathrm{~km}$ of impact-related rocks.

\section{ICDP Drilling Project Operations}

After surface studies were more or less exhausted by early 2000, it was decided to pool the efforts for drilling in the form of a multi-national and multi-disciplinary study. A full proposal was submitted to the ICDP and approved in mid 2002 for $70 \%$ of the total cost. The principal investigators of that proposal (C. Koeberl, B. Milkereit, J. Overpeck, and C. Scholz) had to raise the remaining funds from their own national sources. After many logistical, financial, and technical challenges, and with the help from

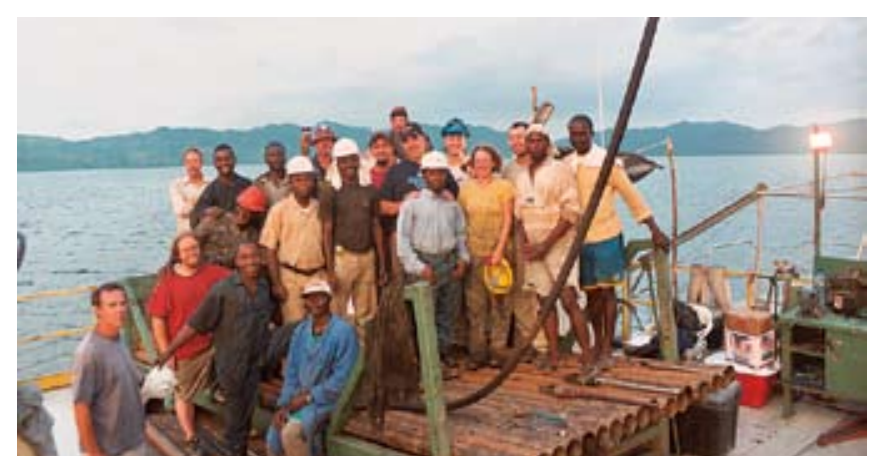

Figure 3. Group photo of sediment drilling team at Lake Bosumtwi after having completed site 4 to rock at a depth of 240 mblf. back row (I-r): Donald Bagley, James Addo, Sylvester Blay, Dave Altman, Kevin Loveland, Chris Walters (far back), Doug Schnurrenberger, Adam Carey, Tim Shanahan; middle row (I-r): Jannadi Lapukenu, Daniel Somuah, Eric Boahen, Bernard Worlanyo, Anna Henderson, Anthony, Kofi; front row (I-r): Jack Greenberg, Chip Heil, Ailwasi Opoku, Kwame Ahumah. Not shown (on shore): Phil Fox, Brad Hubney, Chris Delahunty. 


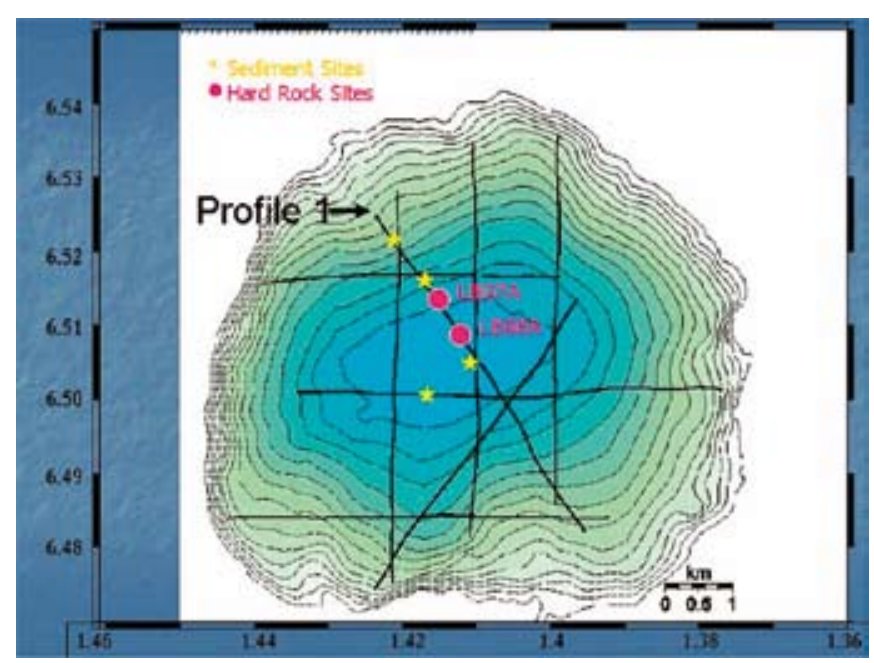

Figure 4. Location map with ICDP boreholes and seismic profile shown in Fig. 6 .

the government of Ghana and the University of Science and Technology in Kumasi, the drilling operations started at the beginning of July 2004 and were completed in early October 2004. Drilling was accomplished using the Global Lake Drilling $800 \mathrm{~m}$ (GLAD800) coring system (Fig. 1), which is a joint operation of the Consortium for Drilling, Observation and Sampling of the Earth's Continental Crust (DOSECC) and the ICDP. The project was unique for the GLAD800 lake drilling system because lake sediment was collected first, and then, after a change in coring instrumentation, the underlying impact rock was collected by diamond coring. For the sediment sampling, five drilling sites were occupied along a water-depth transect to facilitate the reconstruction of the lake level history, and for the hardrock drilling, one of those sites was revisited and another new one was drilled. At these drilling sites, a total of 16 separate holes were drilled. Most of the people on the sediment drilling team are shown in Fig. 3.

\section{Geophysics and Impact Results}

The new deep drill holes LB07A and LB08A are tied to the potential field and seismic data that define the Lake Bosumtwi impact structure (Fig. 4). Acquisition of zero- and multi-offset vertical seismic profiling (VSP) data in deep hardrock holes LB07A and LB08A (Fig. 4) established a link with existing seismic data. Slim-hole borehole geophysical studies provide crucial information about the distribution of magnetized formations within the breccia and help locate discontinuous melt units in the proximity of the scientific drill hole(s). Information about the distribution of magnetic susceptibility and remanance of breccias and impact melt holds the key to an improved three-dimensional model for the Bosumtwi crater and its thermal history. Multioffset VSP supports the integration of conventional logs and existing grid of multi-channel seismic and refraction seismic data. The offset VSP experiments are well suited integrating core data and $\log s$ and converting reflection seismic images from time to depth. By documenting the distribution of magnetic susceptibility and the impact related thermo-magnetic remanance, the distribution of the thermal effects of the impact will be outlined. Combining the horizontal resolution of the seismic surveys with the enhanced vertical resolution of the borehole magnetic surveys provides an ideal set-up for 3-D modeling through data integration.

The hardrock drilling phase, as well as borehole logging and geophysical studies, were completed in October 2004. During that phase, two boreholes to depths of 540 and $450 \mathrm{~m}$, respectively, were drilled in the deep crater moat and on the outer flank of the central uplift as identified in seismic profiles. This represents about $200 \mathrm{~m}$ of impactites/ breccias or fractured bedrock, with about $360 \mathrm{~m}$ of core having been recovered in total. Care was taken to make sure that all drilling operations took place on good-quality seismic lines (Fig. 5). In both holes, casing was set through the lake sediment part of the section and drilling with diamond coring tools started at the sediment/impactite (fallback suevite) interface and progressed through the melt rock and impact breccia layer into fractured bedrock.

After completing the drilling operations, the hardrock cores (122 core boxes) were shipped to the GeoForschungsZentrum in Potsdam, Germany, for scanning and documentation; a sampling party took place in late January 2005. For updates and details, see http:// bosumtwi.icdp-online.org/.

\section{Paleoclimatic Studies at Bosumtwi}

In July and August 2004, a sediment drilling program was undertaken to gain greater insight into the role of the tropics in triggering, intensifying, and propagating climate changes, as well as in responding to global and high-latitude changes. Five drilling sites were occupied along a waterdepth transect to facilitate the reconstruction of the lake level history (Fig. 4). At these five drilling sites, a total of fourteen separate holes were drilled. Total sediment recovery was $1833 \mathrm{~m}$. For the first time, the GLAD800 cored an entire lacustrine sediment fill from lake floor to bedrock. Although detailed sedimentologic study is just beginning, examination of the core catchers and core section breaks

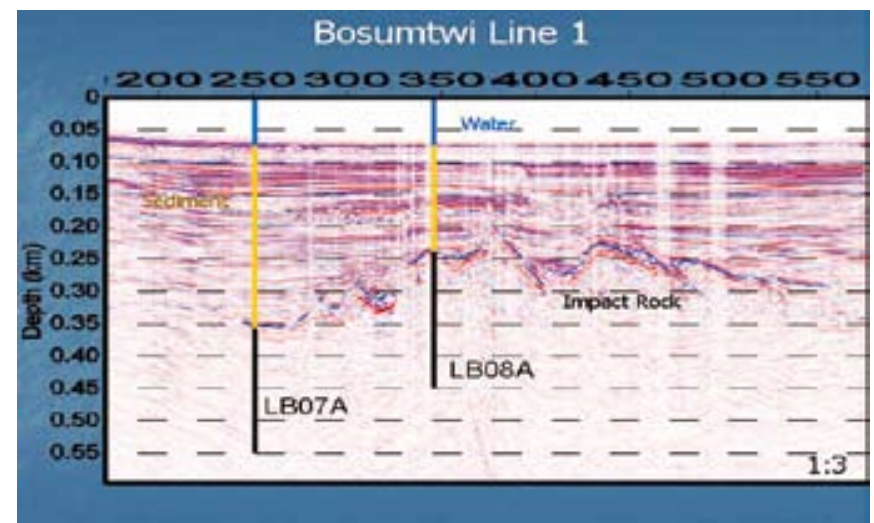

Figure 5. Seismic section (Scholz et al., 2002) with deep boreholes. 


\section{Table 1. Importance and Goals of the Bosumtwi Crater Drilling}

\begin{tabular}{|c|c|}
\hline Importance of Bosumtwi from Impact Perspective & Importance of Bosumtwi from Paleoclimate Perspective \\
\hline $\begin{array}{l}\text { - Largest young impact structure known on Earth } \\
\text { - Extremely well preserved (and easily accessible) } \\
\text { - Detailed geophysical site surveys available } \\
\text { - Source crater of one of only four tektite-strewn fields } \\
\text { - No crater of this size has ever been studied in such } \\
\text { detail (planetary perspectives) }\end{array}$ & $\begin{array}{l}\text { - One of very few long, varved sediment records in the world } \\
\text { - Proven recorder of hydrologic balance and terrestrial ecosystem variability } \\
\text { - Recorder of Sahel aridity and tropical Atlantic sea-surface temperature } \\
\text { variations } \\
\text { - Only known high-resolution recorder of desert dust export from West Africa } \\
\text { - Best possible record for study of long-term, ocean-atmosphere-land surface } \\
\text { interactions in West Africa } \\
\text { - Uniquely valuable record for reconstructing and understanding secular } \\
\text { variations in atmospheric radiocarbon, as well as the variations in solar } \\
\text { output and ocean circulation that cause these variations } \\
\text { - West African location ideal for helping to understand environmental } \\
\text { influences on human and societal evolution over the last } 1 \text { million years }\end{array}$ \\
\hline Drilling Program Goals & Drilling Program Goals \\
\hline $\begin{array}{l}\text { - Crater morphology and geometry studies } \\
\text { - Study of crater fill breccia and melt rocks } \\
\text { - Geophysical studies } \\
\text { - Shock metamorphism studies } \\
\text { - Study of post-impact events } \\
\text { - Astrobiology perspective }\end{array}$ & $\begin{array}{l}\text { - Astronomical-scale environmental variability } \\
\text { - Millennium-scale variability and abrupt climate change } \\
\text { - Interannual to century-scale climate variability } \\
\text { - Tropical ecosystem dynamics and biogeochemistry } \\
\text { - Human-environment interactions } \\
\text { - Hydrocarbon system and source rock dynamics }\end{array}$ \\
\hline
\end{tabular}

during drilling provided glimpses of the paleolimnologic record recovered in the cores (Figs. 6 and 7). The complete 1-m.y. lacustrine sediment fill was recovered from the crater, ending in impact-glass-bearing, accretionary lapilli fallout representing the initial days of sedimentation. The lowermost lacustrine sediment is a bioturbated, light-gray mud with abundant gastropod shells suggesting that a shallow-water oxic lake environment was established in the crater. Future study of the earliest lacustrine sediment will address important questions related to the formation of the lake and the establishment of biologic communities following the impact. Much of the overlying $294 \mathrm{~m}$ of mud is laminated (Fig. 8); thus, these sediment cores will provide a unique 1-m.y. record of tropical climate change in continental Africa at extremely high resolution. The shallowwater drilling sites consist of alternating laminated lacustrine mud (deep-water environment), moderately sorted sand (nearshore beach environment), and sandy gravel

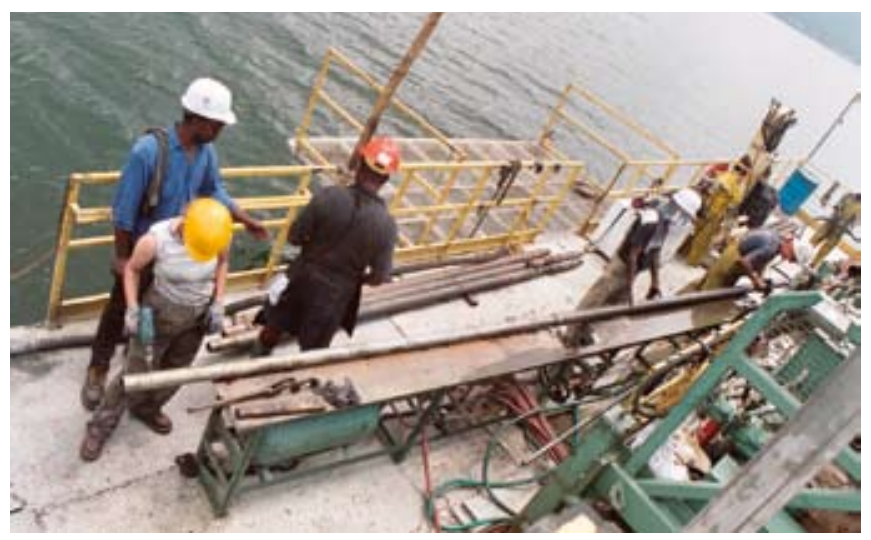

Figure 6. Processing sediment cores. (fluvial or lake marginal environments). These sediments preserve a record of major lake-level variability that will extend the present Bosumtwi lake-level histories obtained from highstand terraces and short piston cores further back in time.

\section{Acknowledgements}

This work was supported by the International Continental Scientific Drilling Program (ICDP), the U.S. National Science Foundation-Earth System History Program under Grant No. ATM-0402010, the Austrian National Science Foundation (project P17194-N10), the Austrian Academy of Sciences, and the Canadian National Science Foundation. We are particularly grateful to the Geological Survey Department of Ghana (P. Amoako, Director) and the University of Kumasi (A. Menyeh, Dean) for logistical support, and to DOSECC (D. Nielson, President) for opera-

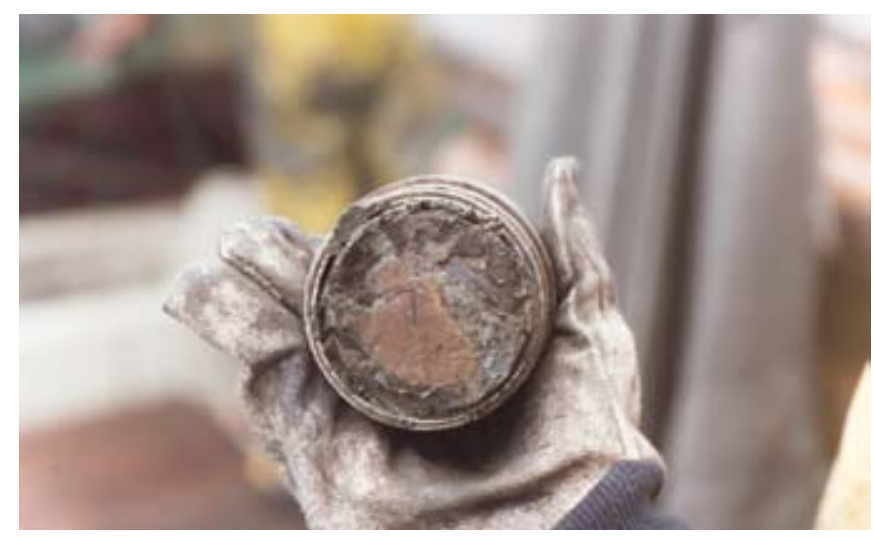

Figure 7. Plant fossil at a section break below 100 mblf. 


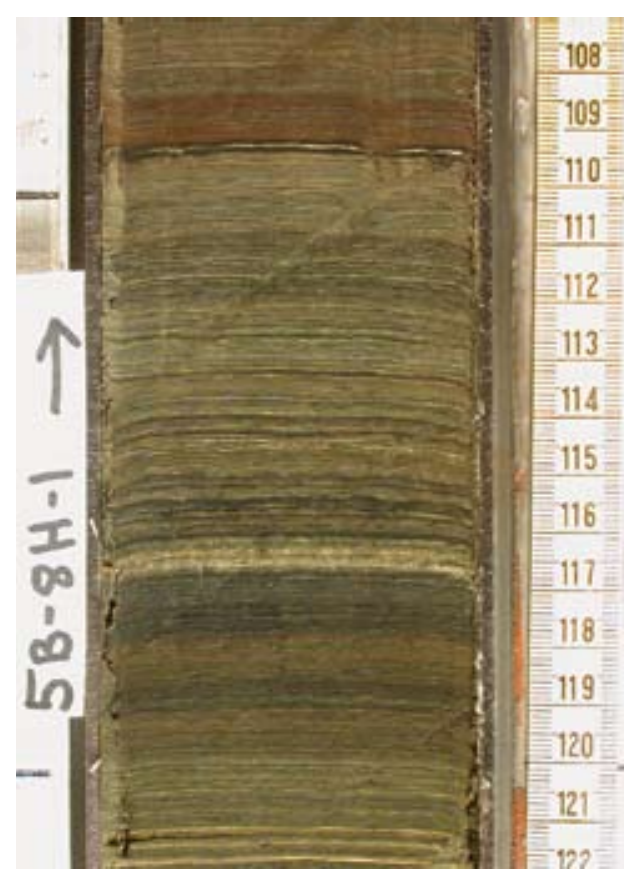

Figure 8. Laminated (and most likely varved) lake sediments from Bosumtwi core.

tional support. Also we appreciate that the project would not have succeeded without the hard work of a dedicated group of DOSECC drillers, the Kilindi captain, local Ghanaian scientists, students, and workers, and a group of international scientists. We also would like to acknowledge the support and hard work of the ICDP operational support group, in particular U. Harms, T. Wöhrl, and J. Kück.

\section{Lake Bosumtwi Drilling Expedition Scientists}

C. Koeberl, J. Peck, B. Hecky, J. King, B. Milkereit, J. Overpeck, C. Scholz, K. Ahumah, M. Baba, E. Boahen, A. Carey, B. Dzirasah, P. Fox, C. Heil, A. Henderson, B. Hubeny, J. Kamuah, D. Schnurrenberger, T. Shanahan, D. Somuah, M. Talbot, E. Boahen, D. Boamah, P. Buchanan, C. Carnein, S. Danuor, P. Claeys, A. Deutsch, R. Gelfort, E. L'Heureux, D. Jalufka, F. Karikari, T. Karp, J. Kueck, H. Newsom, W.U. Reimold, D. Schmitt, R. Shelembe, L. Tober, M. Toepfer, H. Ugalde, and M. Welz.

\section{References}

Brooks, K., Scholz, C.A., King, J.W., Peck, J., Overpeck, J.T., Russell, J.M., and Amoako, P.Y.O., 2005. Late-Quaternary lowstands of Lake Bosumtwi, Ghana: evidence from high-resolution seismicreflection and sediment-core data. Palaeogeogr., Palaeoclimatol., Palaeoecol., 216:235-249.

Karp, T., Milkereit, B., Janle, J., Danuor, S.K., Pohl, J., Berckhemer, H., and Scholz, C.A., 2002. Seismic investigation of the Lake Bosumtwi impact crater: preliminary results. Planet. Space Sci., 50:735-743.
Koeberl, C., Bottomley, R.J., Glass, B.P., and Storzer, D., 1997. Geochemistry and age of Ivory Coast tektites and microtektites. Geochim. Cosmochim. Acta, 61:1745-1772.

Koeberl, C., Reimold, W.U., Blum, J.D., and Chamberlain, C.P., 1998. Petrology and geochemistry of target rocks from the Bosumtwi impact structure, Ghana, and comparison with Ivory Coast tektites. Geochim. Cosmochim. Acta, 62:2179-2196.

Peck, J.A., Green, R.R., Shanahan, T., King, J.W., Overpeck, J.T., and Scholz, C.A., 2004. A magnetic mineral record of late Quaternary tropical climate variability from Lake Bosumtwi, Ghana. Palaeogeogr., Palaeoclimatol., Palaeoecol., 215:37-57.

Plado, J., Pesonen, L.J., Koeberl, C., and Elo, S., 2000. The Bosumtwi meteorite impact structure, Ghana: a magnetic model. Meteorit. Planet. Sci., 35:723-732.

Scholz, C.A., Karp, T., Brooks, K.M., Milkereit, B., Amoako, P.Y.A., and Arko, J.A., 2002. Pronounced central uplift identified in the Lake Bosumtwi impact structure, Ghana, using multichannel seismic reflection data. Geology, 30:939-942.

Talbot, M.R., and Johannessen, T., 1992. A high-resolution paleoclimatic record for the last 27,500 years in tropical West Africa from the carbon and nitrogen isotopic composition of lacustrine organic matter. Earth Planet. Sci. Lett., 110:23-37.

\section{Authors}

Christian Koeberl, Deptartment of Geological Sciences, University Vienna, Althanstrasse 14, Vienna, A-1090, Austria, e-mail: christian.koeberl@univie.ac.at

John Peck, Deptartment Geology, University Akron, Akron, OH 44325, U.S.A.

John King, Grad. School Oceanography, University Rhode Island, Narragansett, RI 02882, U.S.A.

Bernd Milkereit, Deptartment Physics, University Toronto, Toronto, ON M5S 1A7, Canada

Jonathan Overpeck, ISPE, University of Arizona, $715 \mathrm{~N}$ Park Ave. Fl 2, Tucson, AZ 85719-5037, U.S.A.

Christopher Scholz, Deptartment of Earth Sciences, Syracuse University, Syracuse, NY 13244-1070, U.S.A.

\section{Related Weblink}

http://bosumtwi.icdp-online.org/

\section{Figure Credits}

Fig. 1 by Christian Koeberl.

Figs. 3, 6, 7, and 8 by John Peck. 